\title{
Estimation of Gene Action for Seed Yield and Component Traits using Generation Mean Analysis in Pigeonpea [Cajanus cajan
} (L.) Millspaugh]

Tuntun Naing, S.K. Verma, R.K. Panwar, A.K. Gaur, Charupriya Chauhan, Harikant Yadav, Anandi Karn

$10.18805 / L R-4768$

\begin{abstract}
Background: For improvement of quantitative traits the information on nature of gene action is an important asset for plant breeders. However, the information on gene action for yield and its attributes is scanty in pigeonpea crop.

Methods: The present experiment was carried out during kharif 2018-2020 at GBPUAT, Pantnagar, Uttarakhand. The experimental material consisted of six generations of three crosses viz., PADT-16 $\times$ PUSA 992, PADT-16 $\times$ UPAS 120 and PADT- $16 \times$ PAU 881 . The observations were recorded on nine morphological characters. The gene action was estimated by three parameters model of Jinks and Jones if scaling tests were non significant and six parameters model of Hayman if scaling tests were significant.

Result: For majority of traits in all three crosses, epistatic gene action was present as scaling tests were found to be significant. However, for traits number of primary branches, number of secondary branches and number of seeds per pod in cross PADT-16 $\times$ UPAS 120 a simple additive/dominance model was found to be adequate. In general, magnitude of dominance was found to be higher as compared to corresponding additive gene action. The high magnitude of dominance indicated that heterosis breeding is rewarding in these characters.
\end{abstract}

Key words: Generation mean, Gene action, Pigeonpea, Yield.

\section{INTRODUCTION}

Pigeonpea is most important kharif pulse crop of India and is grown extensively by farmers throughout the country. Globally, it is cultivated in Asian, African and Latin American countries on an area of 7.02 million hectare area with an annual production of 6.81 million tons (FAOSTAT, 2017). In order to choose a suitable breeding programme for its further improvement, it is necessary to understand the nature of gene action involved in governing yield and its related traits. The number of genes controlling the trait, type of gene action and genotype $x$ environment interaction are three major factors that must be considered by the plant breeders for the analysis and improvement of quantitative traits (Sprague, 1963). Although, diallel and line $x$ tester analysis are useful in imparting the knowledge about additive variance, dominance variance, gca, sca variances and effects, however, they do not provide the estimates of non-allelic interactions. The partitioning of total genetic variance in to different components i.e., additive, dominance and all types of epistatic interactions will be of immense use in formulating an efficient breeding programme.

Generation mean analysis is a relatively simple and reliable tool as it uses first degree statistics for preliminary estimation of various genetic effects along with estimation and interpretation of non-allelic interactions (Mather and Jinks, 1971). It is considered as best model for estimation of genetic parameters as it uses six basic generations variance components to provide accurate information in
Department of Genetics and Plant Breeding, G.B. Pant University of Agriculture and Technology, Pantnagar-263 145, Uttarakhand, India.

Corresponding Author: Harikant Yadav, Department of Genetics and Plant Breeding, G.B. Pant University of Agriculture and Technology, Pantnagar-263 145, Uttarakhand, India.

Email: harikantyadav588@gmail.com

How to cite this article: Naing, T., Verma, S.K., Panwar, R.K., Gaur, A.K., Chauhan, C., Yadav, H. and Karn, A. (2022). Estimation of Gene Action for Seed Yield and Component Traits using Generation Mean Analysis in Pigeonpea [Cajanus cajan (L.) Millspaugh]. Legume Research. DOI: 10.18805/LR-4768.

Submitted: 11-08-2021 Accepted: 16-11-2021 Online: 07-01-2022

relation to average dominance ratio and inheritance. The greatest merit of Generation mean analysis lies in its ability to precisely estimate epistatic gene effects viz., additive $x$ additive [i], additive $x$ dominance [j] and dominance $x$ dominance [l] (Said, 2014 and Narasimhulu et al.,2018).The study of literature suggested that the information of gene action studies for yield and its related traits by using generation mean analysis is scanty in pigeonpea (Hooda et al., 2000; Kumar et al., 2009). There is an ample scope to exploit the non-allelic gene interactions in pigeonpea and hence information regarding these interactions can be highly useful. Therefore, the present investigation was undertaken 
to estimate various components of gene effects in pigeonpea for its yield improvement.

\section{MATERIAL AND METHODS Plant material and Field trial}

The present experiment was carried out at N.E.B. Crop Research Center, G.B. Pant University of Agriculture and Technology, Pantnagar, Uttarakhand during kharif 20182020. The crosses were attempted between a determinate variety PADT-16 with three indeterminate varieties viz. PUSA 992, UPAS 120 and PAU 881 during kharif 2018 to produce three different types of $F_{1}$ 's viz.,PADT-16 x PUSA 992, PADT$16 \times$ UPAS 120 and PADT-16 x PAU 881. The $F_{1}$ 's were backcrossed with both the parents to generate $B C_{1}$ and $B C_{2}$ generations during the kharif 2019; the $\mathrm{F}_{1}$ 's was also selfed to produce seeds for $F_{2}$ generation. Fresh $F_{1}$ 's was also developed by crossing the determinate variety PADT-16 as female parent with determinate varieties PUSA 992, UPAS 120 and PAU 881 as male during the year 2019. The six generation $\left(P_{1}, P_{2}, F_{1}, F_{2}, B C_{1}\right.$ and $\left.B C_{2}\right)$ of these three different crosses viz.PADT-16 x PUSA 992, PADT-16 x UPAS 120 and PADT-16 x PAU 881 were grown during the kharif season of the year 2020 to generate data on different morphological traits for generation mean analysis.

\section{Observation recorded and statistical analysis}

The observations were recorded for nine different characters viz. days to 50 per cent flowering, days to maturity, plant height $(\mathrm{cm})$, number of primary branches/plant, number of secondary branches/plant, number of pods/plant, number of seeds/pod, 100-seed weight (g) and seed yield/plant (g). In the present investigation, simple scaling test (Hayman and Mather, 1955), Joint Scaling Tests (Cavalli, 1952), three parameters model (Jinks and Jones, 1958) and six parameters model (Hayman, 1958) were applied to estimate various components of gene effect. Non-significance of any of the scaling test signified adequacy of additive dominance model and hence three parameter model (Jinks and Jones, 1958) was used in that particular case. Significance of any of the scaling test signified presence of epistasis and hence six parameter model (Hayman, 1958) was used in such cases. Statistical analysis was carried out using Indostat statistical package.

\section{RESULTS AND DISCUSSION \\ Per se performance and Scaling tests for different characters}

The mean of the six generations of three different crosses for nine characters are presented in Table 1. The hybrids of all three crosses were found to be early in flowering and maturity as compared to indeterminate parent, however, none of the hybrid was found to be early maturing as compared to determinate parent i.e. PADT-16. All three different hybrids possess more plant height than the determinate parent while none of the hybrid had more height than indeterminate parent. The height of $F_{2}, B_{1}$ and $\mathrm{BC}_{2}$ generation was also observed to be more than the determinate parent PADT-16. More plant height is a desirable character in pigeonpea as more plant height means more fruiting branches, more pods which ultimately leads to more seed yield (Verma et al., 2018). The hybrids of all three crosses had more primary and secondary branches as compared to both the parents. The $\mathrm{F}_{2}$ had less primary and secondary branches than $F_{1}$ in all three crosses, hence exhibiting inbreeding depression. The hybrids in all three crosses had high number of pods as compared to both the parents while the $F_{2}$ showed severe reduction in number of number of pods as compared to $F_{1}$. All hybrids except PADT$16 \times$ PUSA 992 had more seeds per pod as compared to both the parents. The $\mathrm{F}_{2}$ and $\mathrm{BC}_{1}$ generation had less seeds per pod as compared to $F_{1}$ in all three studied crosses. In case of 100 seed weight, hybrids performed better than both the parents in all three crosses while the $F_{2}$ exhibited reduction in mean as compared to $F_{1}$ in all three crosses. In case of seed yield the $F_{1}$ performs better than all other generations in all three crosses. The better performance of hybrids for seed yield in pigeonpea was also reported earlier by Meshram et al. (2013). A simple additive/dominance model was found to be adequate as inferred from the nonsignificance of all the scales for number of primary branches, number of secondary branches and number of seeds per pod in cross PADT-16 x UPAS 120. For rest of the characters in all three crosses, epistatic interaction was present as scaling tests were found to be significant (Table 2). The significance of these scales for studied characters in earlier investigations was also reported by Parmar and Kathiria (2016) and Rathore et al. (2019).

\section{Estimation of gene action for yield and related traits}

The additive, dominance and epistatic type of gene interactions in each cross for different trait were found to be different from each other. For both flowering and maturity, all three crosses showed the presence of additive component of genetic variances, however, dominance component were only exhibited by two crosses PADT-16 $x$ UPAS 120 and PADT-16 x PAU 881 (Table 3). The dominance effect exhibited by these two crosses was higher than the corresponding additive component. The high estimates of dominance variance indicated the possibility of exploitation of heterosis in these two crosses. The epistatic component, $i$ (additive $x$ additive) was found to be significant in crosses PADT-16 x PUSA 992 and PADT-16 x PAU 881 while I (dominance $x$ dominance) component was found to be significant in crosses PADT-16 x UPAS 120 and PADT-16 $x$ PAU 881 for both these characters. In the present investigation duplicate epistasis was found to be present in majority of crosses for both the characters. The presence of duplicate gene action indicated that selection should be delayed for later generations till fixation and accumulation of favourable genes. The presence of these kind of gene effects in governing days to $50 \%$ flowering and maturity in 
Estimation of Gene Action for Seed Yield and Component Traits using Generation Mean Analysis in Pigeonpea [Cajanus cajan ...

Table 1: Per se performance of different generations of three crosses for nine characters.

\begin{tabular}{|c|c|c|c|}
\hline CrossesCharacter and generation & PADT-16 x PUSA 992 & PADT-16 x UPAS 120 & PADT-16 x PAU-881 \\
\hline \multicolumn{4}{|l|}{ Days to $\mathbf{5 0 \%}$ flowering } \\
\hline$P_{1}$ & 58.80 & 59.40 & 61.20 \\
\hline $\mathrm{P}_{2}$ & 89.40 & 90.00 & 86.00 \\
\hline $\mathrm{F}_{1}$ & 79.57 & 84.50 & 80.00 \\
\hline $\mathrm{F}_{2}$ & 79.73 & 85.34 & 78.63 \\
\hline $\mathrm{BC}_{1}$ & 76.87 & 81.50 & 61.25 \\
\hline $\mathrm{BC}_{2}$ & 79.50 & 90.25 & 81.20 \\
\hline \multicolumn{4}{|l|}{ Days to Maturity } \\
\hline$P_{1}$ & 113.80 & 114.80 & 115.60 \\
\hline $\mathrm{P}_{2}$ & 144.40 & 145.00 & 139.00 \\
\hline $\mathrm{F}_{1}$ & 134.14 & 139.25 & 134.25 \\
\hline $\mathrm{F}_{2}$ & 134.78 & 140.50 & 133.34 \\
\hline $\mathrm{BC}_{1}$ & 131.25 & 137.00 & 116.25 \\
\hline $\mathrm{BC}_{2}$ & 133.66 & 146.50 & 136.20 \\
\hline \multicolumn{4}{|l|}{ Plant Height $(\mathrm{cm})$} \\
\hline $\mathrm{P}_{1}$ & 140.40 & 139.00 & 133.80 \\
\hline $\mathrm{P}_{2}$ & 254.00 & 292.00 & 224.60 \\
\hline $\mathrm{F}_{1}$ & 241.42 & 220.75 & 239.75 \\
\hline $\mathrm{F}_{2}$ & 199.99 & 225.72 & 176.77 \\
\hline $\mathrm{BC}_{1}$ & 203.12 & 227.37 & 138.75 \\
\hline $\mathrm{BC}_{2}$ & 258.33 & 232.75 & 233.20 \\
\hline \multicolumn{4}{|c|}{ Number of Primary Branches per plant } \\
\hline$P_{1}$ & 13.40 & 12.60 & 15.40 \\
\hline $\mathrm{P}_{2}$ & 16.60 & 13.00 & 18.20 \\
\hline $\mathrm{F}_{1}$ & 19.71 & 19.75 & 20.00 \\
\hline $\mathrm{F}_{2}$ & 10.69 & 14.40 & 12.59 \\
\hline $\mathrm{BC}_{1}$ & 15.12 & 13.75 & 17.00 \\
\hline $\mathrm{BC}_{2}$ & 19.16 & 14.50 & 15.00 \\
\hline \multicolumn{4}{|c|}{ Number of Secondary Branches per Plant } \\
\hline$P_{1}$ & 11.40 & 12.40 & 19.00 \\
\hline $\mathrm{P}_{2}$ & 18.00 & 18.80 & 26.00 \\
\hline $\mathrm{F}_{1}$ & 31.28 & 54.00 & 38.50 \\
\hline $\mathrm{F}_{2}$ & 13.60 & 18.23 & 18.86 \\
\hline $\mathrm{BC}_{1}$ & 20.75 & 18.62 & 71.00 \\
\hline $\mathrm{BC}_{2}$ & 24.16 & 22.25 & 20.20 \\
\hline \multicolumn{4}{|l|}{ Number of Pods per Plant } \\
\hline$P_{1}$ & 128.00 & 136.00 & 133.60 \\
\hline $\mathrm{P}_{2}$ & 272.00 & 204.00 & 119.00 \\
\hline $\mathrm{F}_{1}$ & 337.28 & 321.25 & 325.00 \\
\hline $\mathrm{F}_{2}$ & 167.65 & 162.53 & 131.80 \\
\hline $\mathrm{BC}_{1}$ & 251.00 & 187.50 & 53.50 \\
\hline $\mathrm{BC}_{2}$ & 354.66 & 284.00 & 167.40 \\
\hline \multicolumn{4}{|l|}{ Number of Seeds per Pod } \\
\hline $\mathrm{P}_{1}$ & 2.40 & 2.46 & 2.88 \\
\hline $\mathrm{P}_{2}$ & 4.40 & 4.02 & 4.00 \\
\hline $\mathrm{F}_{1}$ & 4.20 & 4.17 & 4.37 \\
\hline $\mathrm{F}_{2}$ & 3.75 & 3.73 & 3.28 \\
\hline $\mathrm{BC}_{1}$ & 3.88 & 3.90 & 3.50 \\
\hline $\mathrm{BC}_{2}$ & 4.28 & 4.00 & 4.30 \\
\hline
\end{tabular}

Continue... 
Table 1: Continue...

$\begin{array}{llll}\text { One hundred Seed Weight }(\mathbf{g}) & & \\ \mathrm{P}_{1} & & 7.15 & 7.27 \\ \mathrm{P}_{2} & 7.34 & 8.31 & 8.37 \\ \mathrm{~F}_{1} & 8.03 & 8.75 & 8.47 \\ \mathrm{~F}_{2} & 8.82 & 7.75 & 7.35 \\ \mathrm{BC}_{1} & 8.06 & 7.32 & 7.55 \\ \mathrm{BC}_{2} & 8.14 & 8.53 & 7.89 \\ \text { Seed Yield per Plant }(\mathbf{g}) & 7.88 & & 30.93 \\ \mathrm{P}_{1} & & 30.49 & 50.46 \\ \mathrm{P}_{2} & 28.10 & 42.65 & 88.59 \\ \mathrm{~F}_{1} & 54.74 & 90.75 & 33.61 \\ \mathrm{~F}_{2} & 78.28 & 38.38 & 24.90 \\ \mathrm{BC}_{1} & 46.56 & 43.75 & 82.08\end{array}$

pigeonpea was also reported by earlier by Kumar et al. (2009) and Parmar and Kathiria (2016). For plant height all the three crosses except PADT- 16 x PUSA 992 exhibited additive variance. In crosses PADT-16 x PUSA 992 and PADT-16 x PAU 881 both $i$ (additive $x$ additive) and 1 (dominance $x$ dominance) component of epistasis was present. Thus, a breeding procedure that will utilize both additive and dominance components, such as family selection with inter-mating, may be suitable for improvement of plant height. All the three crosses showed the presence of duplicate type of gene action for plant height. The presence of duplicate gene action indicated that selection will not be fruitful and may not lead to much improvement in early segregating generations for plant height and thus it is better that selection should be delayed for later generations till fixation and accumulation of favourable genes. Under such condition subsequent inter mating also becomes important. These results are supported by the findings of Hooda et al. (2000), Singh and Bajpai (2005), Kumar et al. (2009), Parmar and Kathiria (2016) and Rathore et al. (2019) for plant height. For both primary and secondary branches dominance component was found to be higher than the corresponding additive component in all the crosses. The high dominance suggested the use of heterosis breeding for improvement of these traits. Additive $x$ additive epistatic component was found in crosses PADT-16 x PUSA 992 and PADT- $16 \times$ PAU 881 for both primary branches and secondary branches while dominance $x$ dominance epistatic component was found in cross PADT-16 x PUSA 992 for both primary and secondary branches. The additive $x$ additive variance in cross PADT-16 x PUSA 992 and PADT$16 \times$ PAU 881 suggested that pureline method or pedigree method may be useful in the improvement of these traits. The dominance $x$ dominance variance in cross PADT-16 $x$ PUSA 992 suggested the use of heterosis breeding. Similar results for number of primary and secondary branches were also reported earlier by Kumar et al. (2009), Parmar and Kathiria (2016), Obala et al. (2019) and Rathore et al. (2019). For number of pods per plants and number of seeds per pod dominance component was found to be higher than the corresponding additive component in all crosses. The high magnitude of dominance gene action indicated that the heterosis breeding will be rewarding for bringing desirable improvement in these particular traits. The cross PADT-16 $x$ PUSA 992 exhibited both i and I epistatic components for both the traits, however, I type of non-allelic interaction was found to be higher than corresponding i component. Majority of crosses showed duplicate gene action for both these traits except the cross PADT-16 x UPAS 120 which exhibited complementary gene action for number of pods per plant. Similar results for number of pods per plant and seeds per pod were also reported earlier by Kumar et al. (2009), Parmar and Kathiria (2016) Obala et al. (2019) and Rathore et al. (2019). In case of 100 seed weight all crosses except PADT-16 x PUSA 992 exhibited high dominance variance. The additive $x$ additive component was present in cross PADT-16 x UPAS 120 and PADT-16 x PAU 881. Only PADT$16 \times$ PUSA 992 exhibited dominance $x$ dominance. Complementary type of gene action was present in all crosses for 100 seed weight. In case of seed yield per plant the dominance variance was found to be higher that the corresponding additive variance in all the crosses which indicated that heterosis breeding is rewarding for seed yield. All three crosses exhibited both additive $x$ additive as well as dominance $x$ dominance epistatic components. Thus, a breeding procedure that will utilize both additive and dominance components, such as family selection with intermating, may be suitable for improvement of plant height. All three crosses showed the presence of duplicate type of gene action. Similar results for seed yield per plant were also reported earlier by Kumar et al. (2009), Parmar and Kathiria (2016) Obala et al. (2019), Rathore et al. (2019) and Saroj et al. (2020). 
Estimation of Gene Action for Seed Yield and Component Traits using Generation Mean Analysis in Pigeonpea [Cajanus cajan ...

Table 2: Scaling tests in three different crosses of pigeonpea.

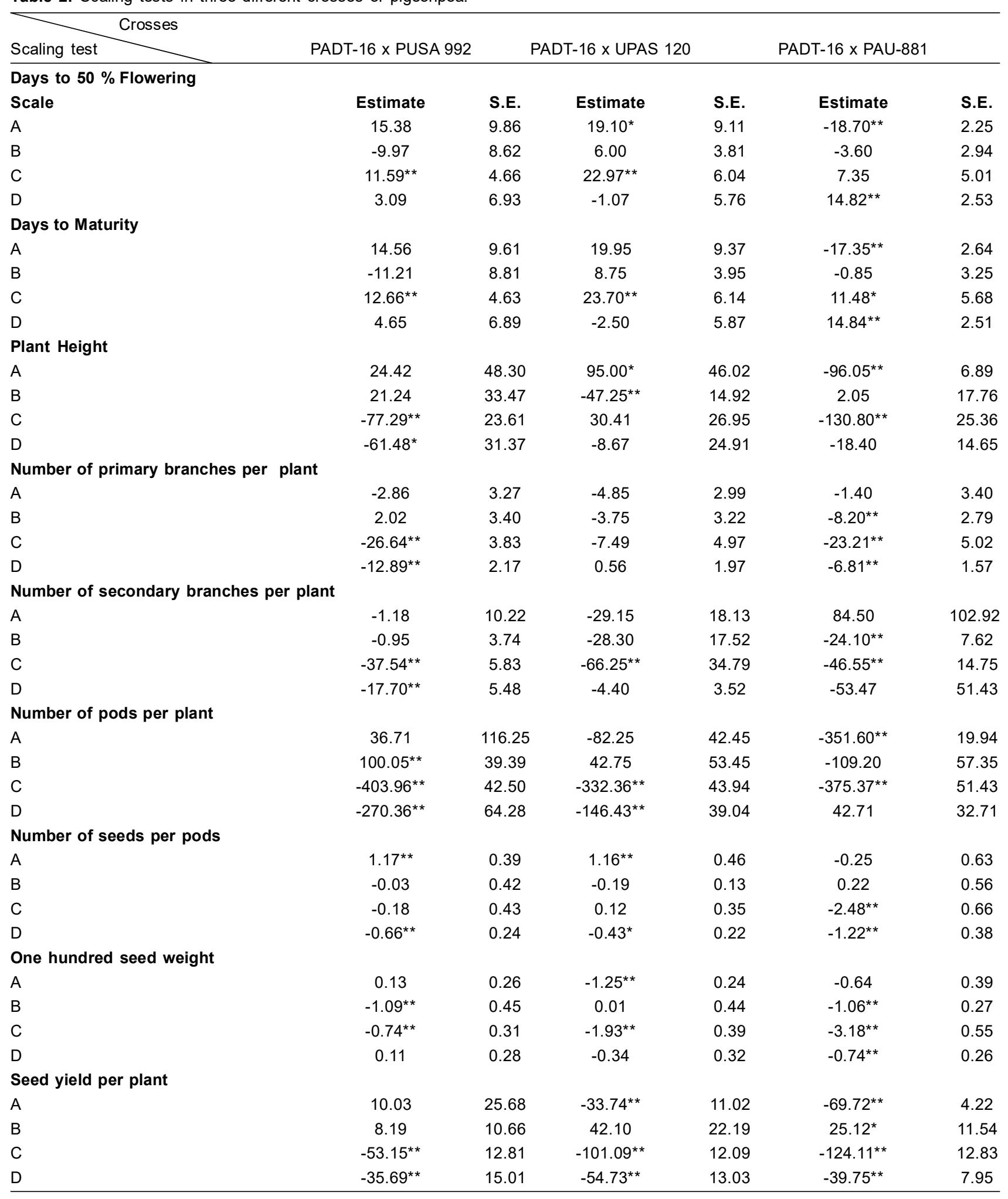


Estimation of Gene Action for Seed Yield and Component Traits using Generation Mean Analysis in Pigeonpea [Cajanus cajan ...

Table 3: Estimates of genetic parameters on basis of joint Scaling tests along with type of epistasis in three crosses for nine characters.

\begin{tabular}{|c|c|c|c|c|c|c|c|c|c|}
\hline \multirow[t]{2}{*}{ Characters } & \multirow[t]{2}{*}{ Crosses } & \multicolumn{6}{|c|}{ Best fitted model on basis of Joint Scaling Test } & \multicolumn{2}{|c|}{ Type of epistasis } \\
\hline & & $\mathrm{m}$ & $d$ & $\mathrm{~h}$ & $\mathrm{i}$ & j & 1 & Complementary & Duplicate \\
\hline \multirow[t]{3}{*}{ DF } & C1 & $79.58^{* *}$ & $-15.28^{* *}$ & & $-5.47^{* *}$ & & & - & + \\
\hline & $\mathrm{C2}$ & $74.69^{* *}$ & $-15.26^{* *}$ & $29.78^{* *}$ & & & $-19.97^{\star \star}$ & - & + \\
\hline & C3 & $108.56^{\star \star}$ & $-12.89^{* *}$ & $-91.15^{\star \star}$ & $-34.68^{* \star}$ & & $62.58^{* *}$ & - & + \\
\hline \multirow[t]{3}{*}{ DM } & C1 & $134.19^{* *}$ & $-15.30^{* *}$ & & $-5.09^{* *}$ & $25.92^{* *}$ & & - & + \\
\hline & C2 & $129.89^{* *}$ & $-15.07^{* *}$ & $31.87^{* *}$ & & & $-22.52^{\star \star}$ & + & - \\
\hline & C3 & $162.76^{* *}$ & $-12.25^{\star *}$ & $-87.96^{\star \star}$ & $-35.17^{\star *}$ & & $59.44^{* *}$ & - & + \\
\hline \multirow[t]{3}{*}{$\mathrm{PH}$} & C1 & & $-56.69^{* *}$ & $547.46^{* *}$ & $197.05^{* *}$ & & $-306.03^{* *}$ & - & + \\
\hline & $\mathrm{C} 2$ & $217.69^{* *}$ & $-77.82^{* *}$ & & & $100.81^{* *}$ & & - & + \\
\hline & C3 & $158.76^{* *}$ & $-45.69^{* *}$ & & $20.78^{* *}$ & $-92.29^{* *}$ & $81.03^{* *}$ & - & + \\
\hline \multirow[t]{3}{*}{ NPB } & C1 & $-10.58^{\star *}$ & $-1.85^{* *}$ & $54.82^{* *}$ & $25.62^{* *}$ & & $-24.52^{* *}$ & - & + \\
\hline & $\mathrm{C} 2$ & $12.62^{* *}$ & & $3.96^{* *}$ & & & & None & \\
\hline & C3 & $5.21^{* *}$ & & $14.77^{* *}$ & $12.05^{* *}$ & & & - & + \\
\hline \multirow[t]{3}{*}{ NSB } & $\mathrm{C} 1$ & $-20.89^{* *}$ & $-3.30^{* *}$ & $85.84^{* *}$ & $35.59^{* *}$ & & $-33.65^{* *}$ & + & - \\
\hline & $\mathrm{C} 2$ & $15.61^{* *}$ & $-3.33^{* *}$ & $7.15^{* *}$ & & & & None & \\
\hline & $\mathrm{C} 3$ & & $-3.49^{* *}$ & $37.92^{* *}$ & $22.51^{* *}$ & $24.71^{* *}$ & & - & + \\
\hline \multirow[t]{3}{*}{ NPP } & C1 & $-391.25^{\star *}$ & $-72.29^{* *}$ & $1507.09^{* *}$ & $591.43^{* *}$ & & $-778.54^{\star *}$ & - & + \\
\hline & $\mathrm{C2}$ & & $-34.44^{* *}$ & $324.41^{* *}$ & $170.18^{* *}$ & & & + & - \\
\hline & C3 & $133.25^{\star *}$ & & $-225.69^{* *}$ & & $-227.89^{* *}$ & $417.44^{* *}$ & - & + \\
\hline \multirow[t]{3}{*}{ NSP } & $\mathrm{C}_{1}$ & $1.95^{* *}$ & $-0.81^{* *}$ & $4.98^{* *}$ & $1.50^{* *}$ & & $-2.73^{* *}$ & - & + \\
\hline & $\mathrm{C} 2$ & $3.74^{* *}$ & $-0.10^{* *}$ & $1.79^{* \star}$ & & & & None & \\
\hline & $\mathrm{C} 3$ & & $-0.55^{* *}$ & $8.63^{* *}$ & $3.42^{* *}$ & & $-4.25^{* *}$ & - & + \\
\hline \multirow[t]{3}{*}{ HSW } & C1 & $7.74^{* *}$ & $-0.32^{* *}$ & & $1.18^{* *}$ & & $1.10^{* *}$ & + & - \\
\hline & $\mathrm{C} 2$ & $6.73^{* *}$ & $-0.58^{* *}$ & $2.01^{* *}$ & $0.99^{* *}$ & $-1.39^{* *}$ & & + & - \\
\hline & C3 & $6.19^{* *}$ & $-0.42^{* *}$ & $2.24^{* *}$ & $1.55^{* *}$ & & & + & - \\
\hline \multirow[t]{3}{*}{ SYP } & C1 & & $-13.59^{* *}$ & $115.98^{* *}$ & $41.65^{* *}$ & & $-37.69^{\star \star}$ & - & + \\
\hline & $\mathrm{C} 2$ & $-12.82^{\star \star}$ & $-6.09^{* *}$ & $104.65^{* *}$ & $49.54^{* *}$ & & $-40.71^{\star \star}$ & - & + \\
\hline & C3 & $-19.01^{* \star}$ & $-9.80^{* *}$ & $108.46^{* *}$ & $59.87^{* *}$ & & $-82.98^{* *}$ & - & + \\
\hline
\end{tabular}

Where, $\mathbf{D F}=$ days to $50 \%$ flowering; $\mathbf{D M}=$ days to maturity; $\mathbf{P H}=$ plant height; $\mathbf{N P B}=$ number of primary branch; $\mathbf{N S B}=$ number of secondary branch; $\mathbf{N P P}=$ number of pods per plant; $\mathbf{N S P}=$ number of seeds per pod; $\mathbf{H S W}=100$-seed weight; $\mathbf{S Y P}=$ seed yield per plant; C1, C2 and C3 refers to the cross PADT-16 x PUSA 992, PADT-16 x UPAS 120 and PADT-16 x PAU 881 ; + refers to presence while - refers to absence.

\section{CONCLUSION}

The results of generation mean analysis for yield and its components revealed that although both additive and dominance type of gene actions were involved in governing studied traits however, in general, magnitude of dominance was found to be higher as compared to corresponding additive gene action. The high magnitude of dominance indicated that heterosis breeding is rewarding in these characters. In case of days of days to $50 \%$ flowering, plant height, number of seeds per pods and seed yield all three crosses exhibited duplicate gene action while in case of hundred seed weight all three crosses exhibited complementary gene action.

\section{ACKNOWLEDGMENT}

The authors are thankful to Department of Agricultural Research, DAR (Ministry of Agriculture, Livestock and Irrigation) Myanmar, Indian Council for Cultural Relations and Joint Director CRC, G.B. Pant University of Agriculture and Technology, Pantnagar for providing all research facilities as and when required during the course of present investigation.

\section{REFERENCES}

Cavalli, L.L. (1952). An analysis of linkage in quantitative inheritance. In: Rieve, E.C.R. and Weddington C.H. eds. Quantitative Inheritance. HMSO, London. pp. 135-144.

FAOSTAT (2017). Food and agriculture organization of the United Nations. Statistical database.

Hayman, B.I. (1958). The separation of epistasis from additive and dominance variation in generation means. Heredity. 12 : 371-390.

Hayman, B.I. and Mather, K. (1955). The description of gene interaction in continuous variation. Biometrics. 11: 69-82.

Hooda, J.S. Tomar, Y.S. Vashistha, R.D and Phogat, D.S. (2000). Generation mean analysis in Pigeonpea [Cajanus cajan (L.) Millsp]. Annals of Biology. 16: 105-109. 
Jinks, J.L. and Jones, R.M. (1958). Estimation of the components of heterosis. Genetics. 43: 223-243.

Kumar, C.S., Sreelakshmi, C.H., Shivani, D. and Suresh, M. (2009). Gene effects for yield contributing characters in pigeonpea [Cajanus cajan (L.) Millsp] by generation mean analysis. Journal of Research ANGRU. 37: 71-76.

Mather, K. and Jinks, J.L. (1971). Biometrical genetics (3rd Ed.). Chapman and Hall Ltd., London.

Meshram, M.P., Patil, A.N. and Abhilasha, K. (2013). Combining ability analysis in medium duration CGMS based hybrid pigeonpea [Cajanus cajan (L.) Millsp.]. Journal of Food Legumes. 26: 29-33.

Narasimhulu, R., Naidu, N.V. and Reddy, K.H.P. (2018). Genetic analysis for yield and yield attributes in greengram [Vigna radiata (L.) Wilczek].Legume Research. (41): 349-355.

Obala, J., Saxena, R.K., Singh, V.K., Kale, S.M., Garg, V., Kumar, C.S. and Varshney, R.K. (2020). Seed protein content and its relationships with agronomic traits in pigeon peais controlled by both main and epistatic effects QTLs. Scientific Reports. 10: 1-17.

Parmar, M.B. and Kathiria, K.B. (2016). Genetic analysis of Seed Yield and Quantitative Traits in Pigeonpea. Global Journal of Research. 5: 2277- 8160.
Rathore, A.S., Bhanu, A., Singh, A.N. and Kumar, M. (2019). Genetic analysis for yield and yield attributing traits in pigeonpea [Cajanas cajan (L.) Millsp.]. Electronic Journal of Plant Breeding. 10: 1240-1245.

Said, A.A. (2014). Generation mean analysis in wheat (Triticum aestivum) under drought stress conditions. Annals of Agricultural Science. 59: 177-184.

Saroj, S.K., Vishwakarma M.K., Singh T., Mishra V.K. and Singh M.N. (2020). Gene action of yield and yield contributing traits of stable $\mathrm{cms}$ based hybrids in pigeonpea [Cajanus cajan (L.) Millspaugh.]. International Journal of Agricultural Science. 12: 9873-9877.

Singh, J. and Bajpai, G.C. (2005). Analysis of gene effects for yield and yield attributing traits in inter specific crosses of Pigeonpea [Cajanus cajan (L.) Millsp.]. Indian Journal of Genetics and Plant Breeding. 65: 133-134.

Sprague, G.F. (1963). Orientation and objectives In "Statistical genetics and plant breeding" National Academy of Science. N.R.C. Pub.982.IX-XV.

Verma, S.K., Gaur, A.K., Bisht, C. and Chandra, D. (2018). Estimation of genetic diversity for yield and its component traits in pigeonpea using $D^{2}$ statistics. Journal of Hill Agriculture. 9: 383-386. 